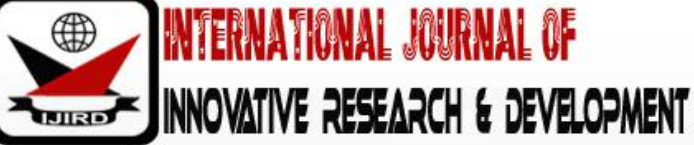

ISSN 2278 - 0211 (Online)

\section{School Farm Three-in-One Concrete Pond Construction Analysis: Implications for Integrating Theory and Practice for Students Acquisition of Sustainable Skill in Fish Farming}

\author{
Fidela Enoidem Udoh
Lecturer, Department of Vocational Education, University of Uyo, Uyo, Akwa Ibom State, Nigeria
Scholastica Fidelis Ekanem
Senior Lecturer, Department of Quantity Surveying, Akwa Ibom State Ploytechnic, Nigeria
Anthony A. Offiong
Associate Professor, Department of Vocational Education, University of Uyo, Nigeria
}

\begin{abstract}
:
The study analysed the quantity and cost of materials of cements and chippings as well as site preparation, plumbing and labour required for the construction of a three-in-one concrete fish pond of 12 × 2 x $1 \mathrm{~m}^{3}$ dimensionThe research was conducted at a homestead research site located at Ifa Atai, Etoi, Uyo Local Government Area of Akwa Ibom State, Nigeria. An experimental design was adopted for the study. Six research questions guided the study. Data were collected on; bill of quantities $(\mathrm{BoQ})$, procurement of materials, execution and payment for labour. The result revealed that 53 bags of cements at $132,500.00$. Three double trips of sharp sand and a single trip of soft sand at $\$ 57,000.00,7$ tons of $20 \mathrm{~mm}$ aggregate of

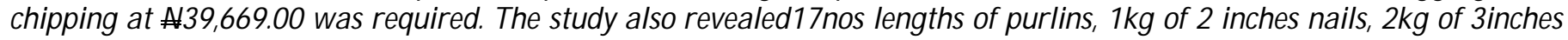
nails and $1 \mathrm{~kg}$ of 4inches nails at $\$ 6,300.00$ was used for site preparation. Four lengths of 4inches pvc pipes, 4inches elbows, 1 tin $90 \mathrm{ml}$ of tangent, 4 nos of 4 inches tees, 4 nos of 4 inches plugs and 4nostaps at\$16,000.00 was used for plumbing. The

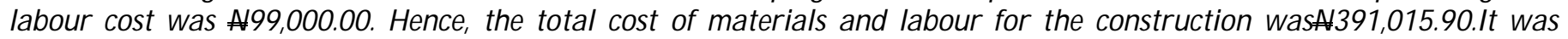
recommended among others that Akwa Ibom State Ministry of Education to study and utilize the result as a guide to embarkon pond construction in school farms, to enhance the integration of theory and practical in the teaching and learning of fish farming for sustainable skill acquisition by students.
\end{abstract}

Keywords: Fish farming, pond construction, practice, sustainable, theory

\section{Introduction}

The innovative technology of cultivation of fish in a controlled water environment, pond fish farming is now taught as trade and entrepreneurial subject in secondary school curriculum.FRN(2014) The objective is to impart on students sustainable skill in the various entrepreneurial opportunities embedded in pond fish farming including fish seeds production, pond construction, rearing of fish,fish processing, marketing of fish and the accessories among others. Udoh(2012) observed that pond fish farming is a source of livelihood in the provision of employment opportunities, generating revenue and providing food to individual and families FAO (2005)opined that the construction of solid, functional and durable pond that houses fish is the basis to establish, develop and flourish in pond fish farming industry. A fish pond is an enclosure capable of holding a large volume of water for a long period of time for fish cultivation. Omitoyin (2002) validated that there are natural as well as artificially constructed ponds. The natural ponds are enclosure bodies of water used for fish farming such as reservoirs, lakes, swamp, shallow sections of rivers, streams and springs carefully demarcated and fenced to hold fish in captivity. While artificial ponds are constructed using available raw materials within a given locality as obtainable in: earthen pond made of clay, wooden pond made of timber, bamboo pond made of bamboo sticks, plastic tank made of rubber, and concrete pond made up of the mixture of cement, sand, chipping and water as the binder. The construction of concrete pond is the focus of this study with reference to materials and labour cost implications. Adewuyi (2012) observed that construction materials constitute a major cost component in any construction project. Chitkara, (2010) validated that construction involves identifying materials, estimating quantities, defining specification, developing procurements plan and monitoring flow of material till the construction work is completed. Hyari (2016) also postulated that construction is the process that sets up a portable plant, bring materials to site and on completion of the work moves the plant away, leaving its output standing. Deriving from the observations Udoh (2012) affirmed that output of concrete pond can be constructed either by laying of moulded blocks, flat slaps or casting of mortar of cement, sand and chipping. Also pond can be built beneath or above the ground level known as excavated and embankment pond respectively. Udoh and Offiong (2017) opined that embankment pond is usually recommended because the height is of advantage. It prevents run-off water from rain, carrying wastes, harmful insects, 
predators not to empty into pond. It also prevents creeping animals like lizards, snakes from creeping into the pond to destroy fish. Embankment pond does not serve as a death trap to domestic animals; dog, goat, cat, chicken and even children. It is also of advantage that concrete pond can be constructed on any soil type, texture and structure provided the pond is build to suit the topography. The study on the analyses of the quantities and cost of materials required for the construction of concrete pond, even in school farmlies on its outstanding benefits when compared to other ponds. Umoren (2014) further observed that concrete pond construction materials like cement, sand and chipping are widely distributed and marketed even in rural areas in Akwa Ibom State. Udoh (2012) validated that concrete pond when constructed by professionals, in compliance to specifications is usually durable and almost of the permanent structure if properly managed and maintained when due. United Kingdom Contractors Group (UKCG) (2009) postulated that a construction is an investment rather than consumption which provides significant long-term economic benefits. Therefore, if concrete pond is constructed in school farms the facilities can sustainably aid in imparting productive practice integrated with theory in fish farming for sustainable skills acquisition by students. Iyare (2014) opined that acquisition of basic knowledge and practical skill in agriculture goes beyond theoretical explanation of concepts that favours psychomotor skill which is the crux of agricultural teaching that elicits the need for field practical to be imparted to student through school farm.

Osinem (2008) equally observed that skill acquisition programmes in school are obtainable by the integration of learning theories, and filed experiences. The observation implies that students' acquisition of skills in fish farming cannot be feasible if learning instruction is limited to classroom without field experience in school farms. Olatain and Mama (2001) defined school farms as a field laboratory design for impacting agricultural knowledge and skills to students through practical. The study is therefore designed to provide materials and labour quantitative analysis for the construction of a three-in-one concrete pond dimension of $12 \times 2 \times 1 \mathrm{~m}^{3}$ in secondary school farms in Akwa Ibom State, Nigeria. Nkantaet al.,( 2017) opted that at the design and planning stage of construction, information regarding the nature, scope, cost and the decisions made is usually influenced by the pre tendered construction analysis of the material, quantity, rate, and cost. Hence, the study on materials and labour cost of constructing a 3-in-1 concrete pond is to provide a quantitative basis on pond construction to school administrators to encourage pond construction in school farms, to facilitate the integration of theory and field practice in the reading and learning of pond fish farming for sustainable acquisition.

\subsection{Three- in- one Concrete Pond}

Three- in-one concrete pond is defined in this paper as a single constructed fish pond structure having three apartments. Amultiple pond apartment built within a common embankment (walls) to fortify strength, minimize land space and reduce cost of construction. Udoh and Offiong (2017) observed that a minimum of 3-4 ponds are usually required for productive fish farming. The multiple ponds allow for the required management practices such as: pond preparation fish sorting, and so on. Example, 'Fish sorting' is a management practice where fish at the culture duration of two to three months are test-harvested, examined, selected and grouped according to growth rate(increase in body size) and re-stocked in separate ponds per the groupings. Sorting gives fish an opportunities to fully access the bio-hydro variables plankton, feed, oxygen, space for rapid growth. Sorting also checks fish cannibalism, overcrowding, stunted growth, water pollution, mortality and poor harvest. The construction of a three-in-one pond in school farms will be of great benefit in minimizing land space as well as reduces materials and construction cost. It was observed by Ruth (2016) that cost is the total money, time, and resources associated with a purchase or activity. Adebiyi and Ekanem (2018)found that owners' knowledge of estimated cost for executing a project usually guide in taking basic decisions whether to undertake a project or not and if undertaken how elaborate and sophisticated the project should be guided by cost estimate made available. Therefore, the study on quantitative analysis of a three-in-one concrete fish pond of $12 \times 2 \times 1 \mathrm{~m}^{3}$ dimension is to provide material and labour cost in the construction of pond in school farms to aid the integration of theory and practice in instruction delivery in fish farming.

\subsection{Purpose of the Study}

The purpose of this study was to determine the quantitative analysis for the construction of three-in-one concrete fish pond dimension of $12 \times 2 \times 1 \mathrm{~m}^{3}$ inschoolfarms.Specifically the study sought to determine:

- The quantitative analysis of cement required for the construction ofa3-in-1 concrete fish pond dimension of $12 \mathrm{x} 2$ $\mathrm{x} 1 \mathrm{~m}^{3}$ in school farms in Akwa Ibom State, Nigeria.

- The quantitative analysis of sand required for the construction of a 3-in-1 concrete fish pond dimension of $12 \times 2 \mathrm{x}$ $1 \mathrm{~m}^{3}$ in school farms in Akwa Ibom State, Nigeria.

- The quantitative analysis of chipping required for the construction of a 3-in-1 concrete fish pond dimension of 12 $\mathrm{x} 2 \mathrm{x} 1 \mathrm{~m}^{3}$ in school farms in Akwa Ibom State, Nigeria.

- The quantitative analysis of materials required for site preparation: site clearing, top-soil excavation, setting-out and trench excavation for the construction of a 3-in-1 concrete fish pond dimension of $12 \times 2 \times 1 \mathrm{~m}^{3}$ in school farms in Akwa Ibom State, Nigeria.

- The quantitative analysis of plumbing materials required for the construction of a 3-in-1 concrete fishpond dimension of $12 \times 2 \times 1 \mathrm{~m}^{3}$ in school farms in Akwa Ibom State, Nigeria.

- The quantitative analysis of labour required for the construction of a3-in-1 concrete fish pond dimension of $12 \times 2$ $\mathrm{x} 1 \mathrm{~m}^{3}$ in school farms in Akwa Ibom State, Nigeria. 


\subsection{Research Questions}

The following research questions where formulated to guide the study:

- What quantitative analysis of cement was required for the construction of a

- three-in-one concrete fish ponddimensi on of $12 \times 2 \times 1 \mathrm{~m}^{3}$ in school farms in

- Akwa Ibom State, Nigeria?

- What quantitative analysis of sand was required for the construction of a three-in-one concrete fish pond dimension of $12 \times 2 \times 1 \mathrm{~m}^{3}$ in school farms in Akwa Ibom State, Nigeria?

- What quantitative analysis of chipping was required for the construction of a three-in-one concrete fishpond dimension of 12 × 2 × $1 \mathrm{~m}^{3}$ in school farms in Akwa Ibom State, Nigeria?

- What quantitative analysis of material was required for site preparation: site clearing, top-soil excavation, settingout, trench excavation for the construction of a three-in-one concrete fish pond dimension of $12 \times 2 \times 1 \mathrm{~m}^{3}$ in school farm in Akwa Ibom State, Nigeria?

- What quantitative analysis of plumbing materials was required for the construction of a three-in-one concrete fish pond dimension of $12 \times 2 \times 1 \mathrm{~m}^{3}$ in school farms in Akwa Ibom State, Nigeria?

- What quantitative analysis of labour was required for the construction ofa three-in-one concrete fish pond dimension of $12 \times 6 \times 1 \mathrm{~m}^{3}$ in school farms in Akwa Ibom State, Nigeria?

\section{Methodology}

The study was conducted at a homestead research site located at Ifa Atai, Etoi, Uyo Akwa Ibom State. Uyo is situated at the South Eastern part of Nigeria. The major agricultural activities carried out within and around Uyo include: crop production; tree crops, fruit trees, tubers crops, root crops and cereals, as well as rearing of farm animals: pigs, poultry, fish, rabbit, goats among others. Uyo lies within the latitude of $5.00^{\circ}$ North and longitude $1.05^{C}$ East. Uyo is the capital city of Akwa Ibom State, Nigeria. An experimental design was adopted for the study. A three-in-one concrete fish pond dimension $12.0 \mathrm{~m}$ length, $2.0 \mathrm{~m}$ width, and $1.0 \mathrm{~m}$ depth $12 \mathrm{x} 2 \mathrm{x}^{\mathrm{m}} \mathrm{m}^{3}$ was constructed. A farm location having flat land and free of noise, pedestrian walk and predators was selected for the construction. The vegetation was cleared and debris carted away from the site. An architectural design was drawn to suit the topography. A quantity surveyor was employed to provide an estimate of the quantities, units, rates, and cost of materials of cements, sand, chipping, formwork, plumbing materials, and labour cost required for the construction. The construction commenced with the procurement of materials, moulding of blocks, site preparation: site clearing, top-soil excavation, trench excavation, block work, casting of foundation footing and floor bed, finishing (plastering), plumbing, and testing of pond water retention capacity for fish stocking. Data were collected on bill of quantities, procurement of materials, execution of the project and payment of labour.The detailed procedures of the construction are presented in stages 1 to 7.

\subsection{Stage 1: Procurement of Materials}

The construction materials of cements, formworks and plumbing were bought and delivered to site at the transportation cost of \#5,000.00 only, while clean borehole water was already available in the farm.

\subsection{Stage 2: Block Moulding}

Twenty two (22) bags of cement were used for moulding of blocks, twenty five(25) pieces of 5 " inches solid block were produced per bag and a total number of 550 blocks were moulded. The limited number of 25 blocks produced per bag was to ensure better quality blocks that can withstand pond water pressure. The blocks were wet with water and allowed for 7 days to cure before putting to use.

\subsection{Stage 3: Site Preparation}

The site was cleared of all vegetations, shrubs, undergrowth and debris carted away from site. Top-soil excavation (removal of 150 millimeters depth to a stable solid level (stripped level) and debris carted away from the site. Settingoutof the works in relation to original points lines and levels of reference given in the drawing for the correctness of the position levels dimension and alignment of all parts of the works was done using sight-rail pegs and robes.

\subsection{Stage 4: Excavation and Treatment:}

Trench excavation for foundation starting from established strip level, maximum depth not exceeding 600mm was dug. The trenches were treated, well leveled and compacted to receive concrete in foundation. Casting of foundation footing with mass concrete mixture of cement, sand and chipping in the ratio of (1:3:6)20mm aggregate respectively were mixed and poured in to foundation trenches. The concrete thickness was $125 \mathrm{~mm}$ to correspond with the five inches $\left(5^{\prime \prime}\right)$ block used for the construction. The blocks were laid in stretcher bond with cement-s and mortar ratio of (1:3) respectively in foundation (beneath the ground).Block in foundation was plastered with cement and sand mixture ratio of (1:3). The plastering was done to strengthen and prevent capillaries movement beneath the ground. Back filling to sides of block works in foundation with excavated materials was equally carried out.

\subsection{Step 5: Treatment, Concreting and Piping}

Treatment (leveling and compaction) of pond base to receive concrete floor bed (garman floor) was done. Plumbing pipes were laid in order to allow for possible adjustment to appropriate levels for effective drainage system before pouring of concrete. Cement, sand, chipping concrete mixture ratio of (1:2:4)20mm aggregate respectively was 
poured on the floor bed. The high quality of concrete mixture was to ensure durability. The block-work in super-structure followed thereafter.

\subsection{Stage 6: Finishing (Plastering)}

Cement and sand mixture ratio (1:3) mortar was used to plaster the inner and outer walls of the pond 2 inches thickness. The finished pond was allowed to stand for three days before testing the water retention strength.

\subsection{Stage 7: Testing of pond Water Retention and Drainage}

Three days after construction, pond water retention and drainage systems were tested. Clean water from an overhead tank was connected through the water in-let channel into the pond. Two-third(2/3) of the pond depth was filled with water. The level of the water in the inner wall of the pond was marked. The water was allowed to stand for 14days and watched out for gradual or sudden reduction in water level. However, it was observed that there was no reduction in the water level. This condition rendered the pond suitable for fish cultivation. On the other hand, a reduction in water level would have indicated leakage thus requiring another plastering.

\section{Data Analysis and Results}

The analysis and results of the research questions are presented on Tables 1-6

\subsection{Research Question 1}

What quantitative analysis of cement was required for the construction of a three-in-one concrete fish pond dimensions of $12 \times 2 \times 1 \mathrm{~m}^{3}$ in school farms in Akwa Ibom State, Nigeria.

\begin{tabular}{|c|c|c|c|c|c|}
\hline S/ N & Cement Requirement & Quantity & Unit & Rate(N) & Cost (N) \\
\hline A & $\begin{array}{c}\text { Block Moulding: } \\
\text { moulding of five inches } \\
\text { (5")blocks }\end{array}$ & 22 & Bags & 2,500 & $55,000.00$ \\
\hline B & $\begin{array}{c}\text { Concrete works } \\
\text { In-situ mass concrete work } \\
(1: 3: 6) \text { 20mm aggregate in: } \\
\text { Foundation footing }\end{array}$ & 6 & Bags & 2,500 & $15,000.00$ \\
\hline C & $\begin{array}{c}\text { In-situ mass concrete work } \\
(1: 2: 4) \text { 20mm aggregate in: } \\
\text { Floor slab (garman floor) }\end{array}$ & 10 & Bags & 2,500 & $25,000.00$ \\
\hline D & $\begin{array}{c}\text { Blockworks } \\
\text { Solid sandcrete blockwork } \\
\text { laid in stretcher bond with } \\
\text { cement and sand (1:3) } \\
\text { mortar. } \\
\text { 125mm wall with size } \\
450 \text { mm x 225mm x 125mm } \\
\text { in foundation }\end{array}$ & 7 & Bags & 2,500 & $17,500.00$ \\
\hline E & $\begin{array}{c}\text { Finishing(Plastering)Extern } \\
\text { ally/ Internally: } \\
14 m m \text { cement and sand } \\
\text { (1:2) rendering finished } \\
\text { troweled smooth on block } \\
\text { work. }\end{array}$ & 8 & Bags & 2,500 & $20,000.00$ \\
\hline Sub-Total & 53 & & & $132,500.00$ \\
\hline
\end{tabular}

Table 1: Quantitative Analysis of Cement Required for the Construction

Ofa Three-In-One Concrete Fish Pond Dimension of 12 X2x 1m³ in School Farms in Akwa Ibom State, Nigeria

The data presented in Table 1 reveals that 22 bags of cement at the rate of $\$ 2,500.00$ and cost of $\$ 55,000.00$ was used for moulding of blocks, 6 bags at the rate of $\mathbf{N} 2,500.00$ and the cost of $\mathbf{N} 15,000.00$ was used for concrete in foundation, while concrete floor bed 10 bags at cost of N25,000.00 was used. Moreso,7 bags at the cost of $\$ 17,500.00$ was used for block laying and 8 bags at the cost of $\mathrm{N} 20,000.00$ was used for plastering. A total quantity of 53 bags of cements at the cost of $\mathrm{N} 132,500.00$ only was required for the construction of a 3-in- 1 concrete pond dimension $12 \mathrm{x} 2 \mathrm{x} 1$ cubic metres $\left(\mathrm{m}^{3}\right)$.

\subsection{Research Question 2}

What quantitative analysis of sand was required for the construction of a three-in-one concrete fish pond dimension of 12 × 2 × $1 \mathrm{~m}^{3}$ in schoolfarms in Akwa Ibom State, Nigeria? 


\begin{tabular}{|c|c|c|c|c|c|}
\hline S/ N & Sand Requirement & Quantity & Unit & Rate (N) & Amount (N) \\
\hline A & $\begin{array}{c}\text { Sharp sand for moulding } \\
\text { of 5 inches blocks }\end{array}$ & 2 & $\begin{array}{c}\text { Double } \\
\text { Trips }\end{array}$ & 16,000 & $32,000.00$ \\
\hline B & $\begin{array}{c}\text { Sharp sand for laying of } \\
\text { block wall and casting of } \\
\text { concretepond floor slab }\end{array}$ & 1 & $\begin{array}{c}\text { Double } \\
\text { Trip }\end{array}$ & 16,000 & $16,000.00$ \\
\hline C & $\begin{array}{c}\text { Soft sand for finishing } \\
\text { (plastering) }\end{array}$ & 1 & $\begin{array}{c}\text { Single } \\
\text { Trip }\end{array}$ & 9,000 & $9,000.00$ \\
\hline & Sub-Total & 4 & & & $57,000.00$ \\
\hline
\end{tabular}

Table 2: Quantitative Analysis of Sand required for the Construction of a

Three-In- One Concretefish Pond Dimension of 12 X 2 X 1 Min

School Farms Inakwa Ibom State, Nigeria

Table 2 reveals that 2 double trips of sharp sand at the rate of $\mathrm{N16,000.00}$ and the cost of $\mathrm{N} 32,000.00$ was used for moulding of block. A double trip of sharp sand at the cost of N16,000.00 was used for casting of foundation, casting of concrete floor bed and laying of blocks both in sub-structure and super-structure. While a single trip of soft sand at the cost of N9,000.00 was used for plastering. A total of three doubles trips of sharp sand and a single trip of soft sand at the cost of N57,000.00 was required for the construction.

\subsection{Research Question 3}

What quantitative analysis of chipping was required for the construction of a three-in-one concrete fish pond dimension of $12 \times 2 \times 1 \mathrm{~m}^{3}$ in school farm in Akwa Ibom State, Nigeria?

\begin{tabular}{|c|c|c|c|c|c|}
\hline S/ N & $\begin{array}{c}\text { Chipping } \\
\text { Requirement }\end{array}$ & Quantity & Unit & Rate (N) & Cost(N) \\
\hline A & $\begin{array}{c}\text { Casting of foundation } \\
\text { footing and concrete } \\
\text { floor slab (garman } \\
\text { floor) }\end{array}$ & 7 & Tone & $5,667.00$ & $39,669.00$ \\
\hline & Sub-total & 7 & & $5,667.00$ & $39,669.00$ \\
\hline
\end{tabular}

Table 3: Quantitative Analysis of Chipping Required for the Construction of a Three-In-One concrete Fish Pond Dimension of 12x2 X1m³in The School Farm in Akwa Ibo state, Nigeria

Table 3 shows that 7tons of chipping (20mm) aggregate at the rate of N5,667.00 and the cost of $\$ 39,669.00$ only was required for the construction of a three-in-one concrete fish pond in Akwa Ibom State, Nigeria.

\subsection{Research Question 4}

What quantitative analysis of material was required for site preparation: site clearing, top soil excavation, settingout and trench excavation for the construction of a three-in-one concrete fish pond dimension of $12 \times 6 \times 1 \mathrm{~m}^{3}$ in school farms in Akwa Ibom State, Nigeria?

\begin{tabular}{|c|c|c|c|c|c|}
\hline S/ N & Site Requirements & Quantity & Unit & Rate (N) & Cost (N) \\
\hline & Site preparation & - & - & - & - \\
\hline A & Setting-out & & & & \\
& i.2"x2"x12" Purlins & 17 & no & 300 & $5,100.00$ \\
& ii.2" nails & 1 & $\mathrm{Kg}$ & 300 & 300.00 \\
& iii.3" nails & 2 & $\mathrm{Kg}$ & 300 & 600.00 \\
& iv.4" nails & 1 & $\mathrm{Kg}$ & 300 & 300.00 \\
\hline & Top Soil excavation & - & - & - & - \\
\hline & Trench excavation & - & - & - & - \\
\hline & Sub-Total & & & & $\mathbf{6 , 3 0 0 . 0 0}$ \\
\hline
\end{tabular}

Table 4.Quantitative Analysis of Material Required for Site Preparation: Site-Clearing, Top-Soil Excavation, Setting-Out and Trench Excavation for the Construction Ofa 3-In-1concrete Fish Pond Dimension of 12 X 2 X 1 M³ in School Farms In Akwa Ibom State, Nigeria

Data in Table 4 showed that there was no materials requirement in site clearing, Seventeen numbers(17no)lengths of 2"x2"x12"purlins at the cost of N5,100.00 and one kilogram (1kg) of 2 inches nails, $2 \mathrm{~kg}$ of 3 inches nail, and $1 \mathrm{~kg}$ of 4 inches nailatthe cost\$300.00, N600.00 and \$300.00 respectively was required for setting-out. Top-soil excavation and trenches excavation required no materials. The cost of material for site preparation was $\mathrm{N}$ $6,300.00$ only. 


\subsection{Research Question 5}

What quantitative analysis of plumbing materials was required for the construction of a three-in-one concrete fish pond dimension of $12 \times 2 \times 1 \mathrm{~m}^{3}$ in school farm in Akwa Ibom State, Nigeria?

\begin{tabular}{|l|c|c|c|c|c|}
\hline S/ N & $\begin{array}{c}\text { Plumbing } \\
\text { Requirement }\end{array}$ & Quantity & Unit & Rate (N) & Cost (N) \\
\hline 1. & 4 inches PVC & 4 & Lengths & 1,200 & $4,800.00$ \\
\hline 2. & 4 inches Elbow & 4 & Numbers(nos) & 600 & $2,400.00$ \\
\hline 3. & Tangent (90 ml) & 1 & Tin & 2,000 & $2,000.00$ \\
\hline 4. & 4 inches Tee & 4 & Numbers(nos) & 600 & $2,400.00$ \\
\hline 5. & 4 inches Plug & 4 & Numbers(nos) & 600 & $2,400.00$ \\
\hline 6. & 4 inches Tap & 4 & Numbers(nos) & 500 & $2,000.00$ \\
\hline \multicolumn{2}{|c|}{ Sub-Total } & & & & $16,000.00$ \\
\hline
\end{tabular}

Table 5: Quantitative Analysis of Plumbing Materials Required for the Construction of A3In-1 Concretefish Pond Dimension of 12 X 2 X $1 \mathrm{M}^{3}$ in School Farms Inakwa

Ibom State, Nigeria

Table 4 revealed that 4 lengths of 4 inches PVC pipes at the cost of $14,800.00$ four(4nos) of 4 inches elbow at the cost of $\$ 2,400.00$, four( 4 nos) of 4 inches Tee at the cost of $\mathbf{2} 2,400.00$, four(4nos) of 4 inches plugs at the cost of $N$ $2,400.00$, and four (4nos) of 4 inches tap at the cost of $\$ 2,000.00$ were needed. The sum total revealed that\$16,000.00 only was required for plumbing.

\subsection{Research Question 6}

What quantitative analysis of labour was required for the construction of a 3-in-1 concrete fish pond dimension of 12 × 2 x $1 \mathrm{~m}^{3}$ in school farms in Akwa Ibom State, Nigeria?

\begin{tabular}{|c|c|c|c|c|c|}
\hline $\mathbf{S} / \mathbf{N}$ & Labour Cost Description & Quantity & Unit & Rate (N) Man-day & Cost (N) \\
\hline \multirow[t]{2}{*}{$\mathrm{A}$} & Moulding of blocks & 22 & Bags & 500 & 11,000 \\
\hline & Sub-Total & & & & $11,000.00$ \\
\hline \multirow[t]{6}{*}{ B } & Site Preparation & & & & \\
\hline & Site clearing & 1 & Labourer & 2,000 & $2,000.00$ \\
\hline & $\begin{array}{l}\text { - } \quad \text { Setting out: } \\
\text { i. } \quad \text { Skilled man } \\
\text { ii. }\end{array}$ & $\begin{array}{l}1 \\
1\end{array}$ & $\begin{array}{l}\text { Builder } \\
\text { labourer }\end{array}$ & $\begin{array}{l}3,000 \\
2,000\end{array}$ & $\begin{array}{l}3,000.00 \\
2,000.00\end{array}$ \\
\hline & - $\quad$ Top-soil excavation & 2 & Labourers & 2,000 & $4,000.00$ \\
\hline & Trenches excavation & 2 & Labourers & 2,000 & $4,000.00$ \\
\hline & Sub-Total & & & & $15,000.00$ \\
\hline \multirow[t]{8}{*}{$\mathrm{C}$} & Concrete Works & & & & \\
\hline & Casting of foundation footing & & & & \\
\hline & Skilled man & 1 & Mason & 3,000 & $3,000.00$ \\
\hline & Semi-skilled man & 3 & Labourers & 2,000 & $6,000.00$ \\
\hline & $\begin{array}{l}\text { Casting of floor slab, (garman } \\
\text { floor) }\end{array}$ & & & & \\
\hline & Skill man & 2 & Mason & 3,000 & $6,000.00$ \\
\hline & Semi-skilled man & 5 & Labourers & 2,000 & $10,000.00$ \\
\hline & Sub-Total & & & & $25,000.00$ \\
\hline \multirow[t]{4}{*}{$\mathrm{D}$} & Block Work & & & & \\
\hline & $\begin{array}{l}\text { I .Laying of blocks in } \\
\text { foundation/ super-structure }\end{array}$ & 3 & Masons & 3,000 & $9,000.00$ \\
\hline & ii. Semi-skilled men & 3 & Labourers & 2,000 & $6,000.00$ \\
\hline & Sub-Total & & & & $15,000.00$ \\
\hline \multirow[t]{4}{*}{$\mathrm{E}$} & Finishing (plastering) & & & & \\
\hline & i. Skilled man & 2 & 2 & 3,000 & $6,000.00$ \\
\hline & ii. Semi-skilled man & 1 & 1 & 2,000 & $2,000.00$ \\
\hline & Sub-Total & & & & $8,000.00$ \\
\hline \multirow[t]{3}{*}{$\mathrm{F}$} & Plumbing Work & & & & \\
\hline & i. Skilled man & 1 & Plumber & 3,000 & $3,000.00$ \\
\hline & $\begin{array}{l}\text { ii. Semi-skilled man } \\
\text { Sub-total }\end{array}$ & 1 & Labourer & 2,000 & $\begin{array}{l}2,000.00 \\
5,000.00\end{array}$ \\
\hline \multirow[t]{2}{*}{$\mathrm{G}$} & Architectural Drawing & 1 & Architect & 20,000 & $20,000.00$ \\
\hline & Grant-Total & & & & $99,000.00$ \\
\hline
\end{tabular}

Table 6: Quantitative Analysis of Labour Required for the Construction of a 3-In-1concrete Fish Ponddimension of 12 X 2x 1min School Farms in Akwa Ibom State, Nigeria 
Table 6 revealed thelabour costof 11 11,000.00 formoulding of blocks, \$15,000.00 for site preparation\$25,000.00

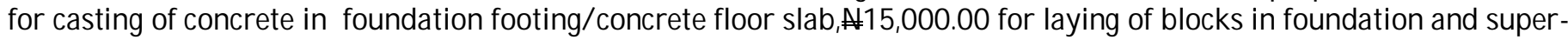
structure, $\mathrm{N} 8,000.00$ for plastering, $\mathrm{N5}, 000.00$ forplumbingand $\mathrm{N20,000.00}$ for architectural drawing.The results revealed that $\$ 99,000.00$ only was required for the payment of labour cost for the pond construction.Architectural drawing floor plan of the 3-in-1 concrete fish pond is shown in figure 1.

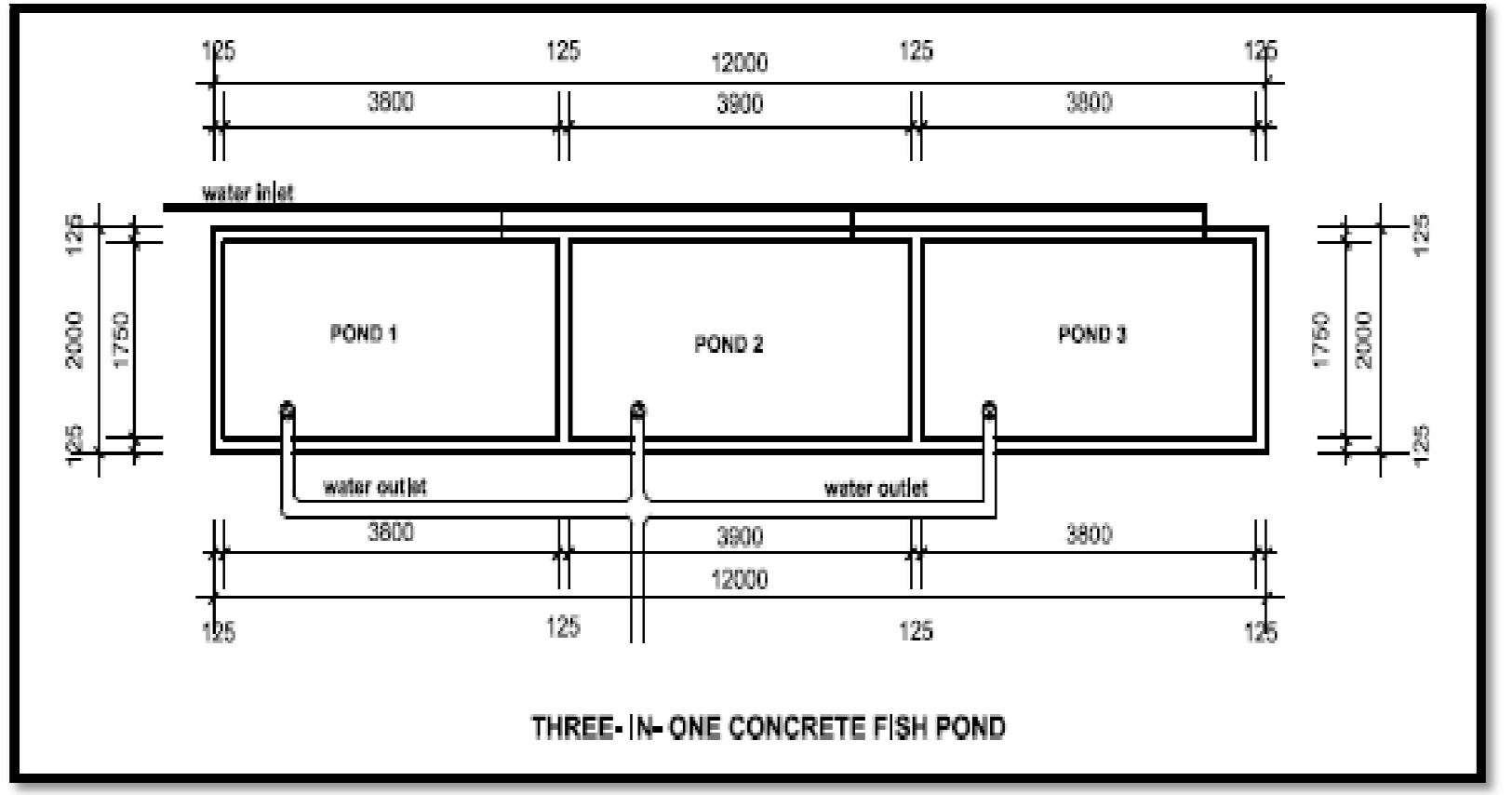

Figure 1: Architectural Drawing of the Floor Plan of a 3-In-1 Concrete

Fish Pond $12 \times 2 \times 1 \mathrm{~m}^{3}$ Dimension

Source: Field Work (2019)

\section{Result and Discussion}

The results on the quantitative analysis of construction materials of cement, sand, chipping and formwork required for constructing $12 \times 2 \times 1 \mathrm{~m}^{3}$ dimension of concrete fish pond in school farms revealed that 53 bags of cements at the cost of 132,500.00 only was require. The cement was used for block moulding, laying of foundation, casting of concrete floor bed, laying of blocks wall and plastering to finishing.

The analysis of chipping revealed that 7 tons of $20 \mathrm{~mm}$ aggregate at $\mathrm{N} 39,669.00$ was required for the foundation footing and concrete floor bed. The quantitative analysis of sand revealed Three (3) double trips of sharp sand and a single trip of soft sand at the cost of $\$ 57,000.00$ was required. The sand was used for block moulding, casting of foundation footing and floor bed, mortar for laying of blocks and plastering of the walls.

The cost analysis of materials for formwork revealed that 17numbers of 2"x2"x12"purlins, 1 kilogramme (kg) of 2", 4" and $2 \mathrm{~kg}$ of $3^{\prime \prime}$ nails at the cost of $\$ 6,300.00$ was required. The purlins and the nails were used for setting-out of the pond construction as specified in the drawing.

The analysis of plumbing material revealed that 4"pvc pipes, 4"elbows, a tin tangent gum, 4"tees, 4"plugs, and 4 "taps at $\$ 16,000.00$ was required for water in-let and out-let water drainage within and out of the pond. Therefore, the total cost of materials of cement, sand, chipping, formwork, plumbing and transportation of materials stood at N256,469.00, while the entire cost of the pond construction was $\$ 391,015.90$ as indicating on Table 9. The analysis revealed that materials cost was the leading factor in the construction. This result is in support of the findings by Adewuyi (2012) that construction materials constitute a major cost component in any construction project. Adewuyi further explained that the total cost of material may be $50 \%$ or more of a total cost construction work as applicable in the study. The summary of the quantitative analysis is presented in Table 7.

\begin{tabular}{|l|c|c|}
\hline \multicolumn{1}{|c|}{ S/ N } & Materials & Cost $\mathbf{A}$ \\
\hline a. & Cement & $132,500.00$ \\
\hline a. & Sand & $57,000.00$ \\
\hline b. & Chipping & $39,669.00$ \\
\hline c. & Site Preparation (Formwork/ nails) & $6,300.00$ \\
\hline d. & Plumbing & $16,000.00$ \\
\hline f. & Transportation & $5,000.00$ \\
\hline & Total & $256,469.00$ \\
\hline
\end{tabular}

Table 7: Summary of Materials Cost Required for the Construction of $12 \times 2 \times 1 \mathrm{~m}^{3}$ Concrete Fish Pond in School Farms in Akwa Ibom State, Nigeria 
The quantitative analysis on the labour cost required for the construction revealed that a total $\mathrm{N} 99,000.00$ was paid for labour as specified:N11,000.00was paid for moulding of blocks, $\mathbf{2} 20,000.00$ for architectural drawing, $\mathrm{N15}, 000.00$ for site preparation, $\mathbf{N 2 5 , 0 0 0 . 0 0}$ for concrete in footing and floor bed,\$15,000.00for laying of blocks, $\mathbf{N} 8,000.00$ for plastering and\$5,000.00 only for plumbing the pond. The analysis revealed that the cost of labour was $\$ 99,000.00$ less than the cost of material of 256,469.00. This implies that labour cost is also very important in the analysis of pond construction because it is the price paid to acquire, produce and accomplish a project. (Anunike, 2015). More so, the labourer actually executed the project and should be paid to motivate quality output.The summary of the labour cost is presented in Table 8.

\begin{tabular}{|c|c|c|}
\hline S/ N & Labour & Cost N \\
\hline A & Block Moulding & $11,000.00$ \\
\hline B & Site Preparation (labour) & $15,000.00$ \\
\hline C & Casting of Concrete & $25,000.00$ \\
\hline D & Laying of Blocks & $15,000.00$ \\
\hline E & Plumbing & $5,000.00$ \\
\hline F & Plastering & $8,000.00$ \\
G & Architectural Drawing & $20,000.00$ \\
\hline & Total & $99,000.00$ \\
\hline
\end{tabular}

Table 8: Summary of Labour Cost of Quantitative Analysis Required for the

Construction12x2x1m³ Dimension of a Three-In-One Concrete Fish Pond In School Farms In Akwa Ibomstate, Nigeria

The grant total cost for the construction of a 3-in-1 concrete pond in school farm in Akwa Ibom State, Nigeria, showed material cost of $=\mathbb{N} 256.469 .00$, labour cost of $=N 99,000.00$, and $10 \%$ contingency of the total cost of the project was $=\$ 35,546.90$. The submission gave the grant total sum of $\$ 391,015.90$ only as shown in Table 9.The quantitative analysis estimate of pond construction is therefore necessary before undertaking the project. This finding is in line with Adebiyi and Ekanem (2018) that the client knowledge of estimate cost for carrying out a project usually guide in taken basic decisions guided by cost estimate made.

\begin{tabular}{|c|c|}
\hline Total & Cost N \\
\hline Materials Cost & $256,469.00$ \\
\hline Labour Cost & $99,000.00$ \\
\hline Contingency(10\% of total sum) & $35,546.90$ \\
\hline GRAND TOTAL & $391,015.90$ \\
\hline
\end{tabular}

Table 9: Summary Grand Total Cost Required for the Construction of 12x2x1m³ Dimension of a Three-In-One Concrete Fish Pond in School Farms in Akwa Ibom State, Nigeria

\section{Educational Implication}

The emphasis of the study on construction of concrete pond in school farm lies on it advantages over other pond facilities; the construction materials of cement, sand, chipping are widely distributed and marketed both in the rural and urban areas, where secondary schools are located in Akwa Ibom State. Udoh (2012) opined that concrete pond when constructed following specification and handled by skilled professionals is usually durable, almost of permanent structure if managed properly and maintained when due. Also concrete pond can be constructed on any soil type, texture, structure and topography is of advantage as school farms has variation in soil topography determined by locations. Above all the construction ofpond in school farms will facilitate the integration of theory and practice in the teaching of fish farming as trade and entrepreneurial subject for sustainable skill acquisition and national development as stipulated in thenational policy on education (FRN, 2014).

\section{Conclusion}

The study provides quantitative analysis on, the materials, quantities and labour cost required for construction of a 3-in-1 concrete fish pond, 12.mx2.mx1.m cubic metre $\left(\mathrm{m}^{3}\right)$ inschool farms in Akwa Ibom State, Nigeria.Although, the construction materials and labour cost may vary over time depending on the location, change in market pricing (inflation) and the economic situation at a given time, but the quantity and unit of materials require remain over time.

\section{Recommendations}

Based on the findings of the study, the following recommendations were made:

- Ministry of education, secondary schools management board and private schools proprietors should take advantage of the available pond construction analysis to embark on pond construction in school farm to facilitate integration of theory and practice in the teaching and learning of fish farming in schools for sustainable skill acquisition. 
- The non-governmental organization NGO, stake holder and patriotic citizens should identify with secondary schools administrators guided by the analysis to partnerin the construction of fish pond in school farms.

- School hosting communities and parent - teachers association should collaborate with school management in the construction of fish pond in school farms toward helping the rising generation to acquire suitable skill in fish pond farming teaching.

\section{References}

i. Anunike, E. B. 2015, Professional practice and procedure for quantity surveyors and project manager. Kaduna: chukidi prints.

ii. Adebiyi, I. R. and Ekanem, S. F.2018, Post-mortem analysis of bill of quantities for the construction of building and engineering project. Journal of Research in Technology and Engineering Management vol4 $2^{\text {nd }}$ ed 89-100.

iii. Adewuyi T.O. 2012, Construction material waste planning and control techniques on building site in South-South of Nigeria. Unpublished thesis submitted to the postgraduate school University of Uyo, Uyo Akwa Ibom State, Nigeria, In partial fulfillment of the requirements for the award of doctor of philosophy degree in construction management.

iv. Chitkara K.K. 2010, Construction project management: planning, scheduling and controlling 15 ${ }^{\text {th }}$ ed. New Delhi: Tata McGraw Hill. 246-248.

v. FAO 2005, Fish Pond Construction and management (A field guide and extension manuel) technological information materials from NSPFS rural agriculture training workshop in Nigeria (Kaduna Bauchi, Katsina-Ala, Owerri Iguoriaki and Akure) 17th March-8 ${ }^{\text {th }}$ April, 2003.

vi. FRN 2014, National policy on education, Abuja NERDC.

vii. Hyari, K. 2016, Introduction to construction industry: construction project management, department of civil engineering Hashemite University. 1-5.

viii. Iyare, R.2014, Management skill required by agricultural science teachers in utilizing the school farm as an education facility in Edo State, Nigeria Vocational Association Journal (NVAJ) vol.19 $1^{\text {st }} \mathrm{ed}$.

ix. Nkanta, S. D; Akpanebu, I. J. and Udoka, I. S. 2017, Determinants of contractor pre-qualification criteria in A Recessed Economy Nigeria International Journals of Advanced Studies Business and Managementvol.51st ed. 67 86.

x. Olaitan, S. O. and Mama, R. O. 2001, Principle and practices of school farm management. Owerri: cape publishers Int'l Ltd.

xi. Osinem, E. C. 2008, Managing agricultural education, training, resources, principles and methods. Enugu: belong international publishers.

xii. Omitoyin, B. O. 2002, Introduction to fish farming in Nigeria, Mushin, Lagos: royal bird venture.

xiii. Ruth, J. 2015, Overview of cost definitions and costing methods. Raj Nallari, World Bank institute, FREM. http:// projecttools.co.uk/ projectTools/ Estimating.htm access 2019/ 02/ 21.

xiv. Udoh, F.E.2012, Effect of pond culture practices on students' acquisition of skills in homestead fish culture in Akwa Ibom State. An Unpublished Ph.D thesis submitted to the department of vocational education, faculty of education, University of Uyo.

xv. Udoh, F. E.and Offiong, A.A. 2017, Concrete pond management skills required by out of school youths for sustainable fish farming in Akwa Ibom State: Journal of Education Realities (JERA) 4(1) department of vocational education, faculty of education, University of Uyo, Nigeria.

xvi. UKCG, 2009, United Kingdom Contractors Group (UKCG). Construction in the UK economy. The benefits of investment.

xvii. http:/ / v35.upl.Universalpixel.com/ ams/ assets/ NASC532147/ construction\%20in\%2othe\%20UK\%20economy\%2 Obooklet retrieved January 17, 2019.

xviii. Umoren, O. 2014, Site analysis and report. A basic requirement in planning for construction, A paper Presented on $9^{\text {th }}-11^{\text {th }}$ October, 2014. The Nigerian Institute of Quantity Surveyors National Training Workshop, Uyo, Akwa Ibom State, Nigeria. 